\title{
Indocyanine green fluorescence imaging for robotic adrenalectomy
}

\author{
Orhan Agcaoglu ${ }^{*}$, Cemil Burak Kulle ${ }^{1}$, Eren Berber ${ }^{2}$ \\ ${ }^{1}$ Department of General Surgery, Koç University, School of Medicine, Istanbul, Turkey; ${ }^{2}$ Department of General Surgery, Cleveland Clinic \\ Foundation, Cleveland, OH, USA \\ Contributions: (I) Conception and design: O Agcaoglu, E Berber; (II) Administrative support: O Agcaoglu, E Berber; (III) Provision of study materials \\ or patients: O Agcaoglu, E Berber; (IV) Collection and assembly of data: CK Kulle; (V) Data analysis and interpretation: CK Kulle; (VI) Manuscript \\ writing: All authors; (VII) Final approval of manuscript: All authors. \\ Correspondence to: Orhan Agcaoglu. Davutpasa Cad. No:4 Topkapi, Istanbul, Turkey. Email: oagcaoglu@gmail.com.
}

\begin{abstract}
Despite the novel and innovative developments in minimal invasive platforms and the expanding indications regarding adrenal surgery, surgeons are still confronted with some obstacles. The use of intraoperative indocyanine green aims to overcome these problems, but there is still limited data and ongoing debates in terms of robot-assisted adrenal surgery. The aim of this article is to discuss the benefit of indocyanine green fluorescence imaging for robot-assisted adrenalectomy and provide up-to date data.
\end{abstract}

Keywords: Fluorescence imaging; robotic adrenalectomy; minimally invasive surgery; adrenal tumor

Submitted Feb 13, 2020. Accepted for publication Apr 10, 2020.

doi: 10.21037/gs-2019-ra-06

View this article at: http://dx.doi.org/10.21037/gs-2019-ra-06

\section{Introduction}

Owing to the recent improvements in minimally invasive surgery, more surgeons prefer laparoscopic or robotics techniques for adrenal surgery. One of the major properties of adrenal gland is its highly vascularized structure which also makes it a good candidate for the use of fluorescence imaging techniques. As a fluorescence technique, indocyanine green (ICG) was first developed by Kodak Laboratories (Rochester, NY, USA) for photography using near infrared (NIR) imaging technology in 1955 and its first clinical application in adrenal surgery was performed by Manny et al. in 2013 (1). Since then, there has been an enthusiasm and effort for establishing ICG in minimal invasive platforms for adrenal surgery.

Even though there is still scant data in the literature regarding ICG use in robotic adrenalectomy, there are reports showing its safety and efficiency in lateral transabdominal (LT) and posterior retroperitoneal (PR) adrenalectomy procedures (2-6). The aim of this paper is to assess the use of ICG in robotic adrenalectomy.

\section{Biochemical properties of ICG}

ICG is an FDA-approved non-toxic water-soluble tricarbocyanine dye with a molecular mass of 776 dalton, which exhibits fluorescence in the near-infrared (NIR) spectrum of $800 \mathrm{~nm}$ (7). When ICG is administered intravenously, it binds strongly to plasma proteins, especially lipoproteins and cycles in the blood flow. ICG is taken into the cells by a receptor-mediated enzyme called bilitranslocase. Therefore, the accumulation of ICG in various tissues is determined by the differential expression of this enzyme and the amount of blood supply. In the end, ICG enters the hepatic sinusoids, where it is taken up by hepatocytes and ultimately excreted into bile (8).

As other endocrine organs such as thyroid gland, the adrenal glands have a rich blood supply via three main arteries (superior, middle and inferior adrenal artery).

*ORCID Number: 0000-0003-1617-3953. 
Among the intra-abdominal organs, the adrenal glands receive the third greatest blood supply after the kidney and spleen with a blood flow of $1.87 \mathrm{~mL} / \mathrm{min}$ (9). Moreover, due to its dual embryological origin, a peculiar illumination of the gland in particular disease can be seen with fluorescence imaging. We also know that tumors originating from the cortex of the adrenal glands were all found to be hyperfluorescent in contrast to the medulla induced hypofluorescent tumors compared to the surrounding tissue (10).

\section{Dosage and side effects of ICG}

The dosage of ICG during adrenal surgery needs to be adjusted well. It has been reported that too much ICG may cause entire retroperitoneal space fluorescence which can limit the distinction between tumor and healthy tissues, while less application does not provide sufficient contrast between tissues. In both situations the identification of the tumor, the distinction of the resection margins and the preservation of adjacent structures could be extremely difficult (2). Our group prepares a solution by mixing $25 \mathrm{mg}$ of ICG (Akron Inc., Lake Forrest, IL, USA) in $10 \mathrm{~mL}$ of distilled water with a final concentration of $2.5 \mathrm{mg} / \mathrm{mL}$ for robotic adrenalectomy procedures. Besides the dosage of ICG, the timing of its administration is also another important issue. After administration of ICG, fluorescence occurs within 60 seconds in all tissues. Moreover, authors have been reported that ICG is released from the retroperitoneal fatty tissue after 5 minutes and the fluorescence may persist up for 20 minutes $(2,3)$. Therefore, ICG is most effective if it is administered after exposure of the retroperitoneal area, but just before starting the dissection of the adrenal gland.

The administration of ICG can be repeated several times during the surgical procedure to maintain a contrast distinction between the tissues, but care must be given to the lethal dose of $50-80 \mathrm{mg} / \mathrm{kg}$ (3). In our experience most patients require an average of two injection (each $5 \mathrm{mg}$ ), irrespective of BMI and tumor size over the course of their adrenal resection (2-4).

Side effects of ICG can be classified as mild reactions, such as allergic or vasovagal in nature and severe reactions, which are associated with bronchospasm or even cardiac arrest (11). To date, there have been no reported mortalities associated with ICG. The rate of severe reactions has been reported due to the administration of much higher doses than normal requirement limits and approximately as $0.05 \%(11,12)$. Thus, the use of ICG in adrenal surgery is contraindicated in patients with known iodine allergy, previous anaphylaxis to dye injections, renal disease, liver disease and pregnancy (13).

\section{ICG administration during adrenal gland surgery}

Especially, with the introduction of novel and innovative minimal invasive platforms such as robotics, in recent decades, there has been a paradigm shift in terms of the surgical management of adrenal glands. Robotics has advantages including better $3 \mathrm{D}$-optical view and articulated instrumentation leading to fine dissection, lesser postoperative pain and blood loss. Another important advantage of minimally invasive techniques compared to conventional open is the application of ICG. To date, fluorescence platforms include Karl Storz ${ }^{\circledR}$ laparoscope (KARL STORZ Endoskope, Tuttlingen, Germany), PINPOINT $^{\circledR}$ Endoscopic Fluorescence Imaging System (Novadaq Technologies, Inc., Mississauga, ON, Canada) and robotics [Firefly ${ }^{\circledR}$ technology (Intuitive Surgical, Inc.)].

The use of ICG has several outstanding advantages during adrenal gland surgery. It can be administrated easily and helps the surgeon to distinguish the adrenal gland from surrounding retroperitoneal fat, identify the border between the tumor and normal adrenal tissue, dissect along the embryologic planes, preserve important adjacent organs or vascular structures and determine the resection margin.

There are a few publications regarding the feasibility of ICG use for robotic adrenal surgery. These studies suggest the implementation of ICG due its superiority of operative outcomes $(2,5,6,14)$. In one of the largest studies in the literature, our group analyzed one hundred patients in 2018 (10). In this study, a total of $74 \%$ of the tumors were hyperfluorescent compared with the surrounding retroperitoneal tissues, whereas the remaining $26 \%$ were non-fluorescent. This result indicated that adrenal tumors have different patterns of indocyanine green fluorescence based on histologic origin (cortical vs. medullary). In statistical analyses, multivariate analysis revealed adrenal cortex as the only predictor of hyperfluorescence following ICG administration: $95 \%, 33 \%$ and $50 \%$ for tumors of adrenocortical, medullary and other tissue origins respectively (15).

Making use of these radio-pathologic features, partial adrenalectomy (PA) or cortex sparing adrenalectomy can be considered for especially sporadic or hereditary bilateral tumors or tumors in solitary adrenal glands. Adrenal insufficiency followed by bilateral adrenalectomy results 
in lifelong risk of morbidity due to Addisonian crisis of $35 \%$, decreases quality of life and has a mortality rate of $3 \%(16,17)$. These concerns lead to an increasing interest and popularity in partial adrenalectomy. However, the assessment between the preservation of residual cortical functions and the increased risk of local recurrence must be done carefully. On the other hand, Benhammou et al. reported recurrence rates up to $11 \%$ after PA with median follow-up of 9.25 years, whereas in another study Alesina et al. noted only one case with persistent disease after PA with a follow-up of 48 months $(18,19)$. With the application ICG during PA, the border between tumor and healthy adrenal tissue become easily apparent and it facilitates the resection (20). These and other data strongly recommend PA in specific circumstances.

Another controversial issue regarding minimal invasive platforms during adrenalectomy is the duration of the procedures. Determinants of operative time include tumor size, tumor side and pathologic features of the tumor, whereas the surgical approach or technique in terms of laparoscopy $v s$. robot-assisted surgery do not have any significant effects up to recent studies $(6,10,21)$. Even the administration of ICG does not significantly lengthen the operation time and the green illumination on the tumor persists continuously depending on the applied dosage (6).

To date, one of the major debates for choosing a minimally invasive technique is malignant pathology. Many authors reported that minimal invasive platforms may lead to macroscopic incomplete resection, tumor capsule violation, increased conversion rate, and microscopic periadrenal fat invasion on final pathology, which contribute to increased local and port site recurrence and peritoneal carcinomatosis (21-23). According to the current data regarding these issues, there is still scant data, if the administration of ICG could overcome these concerns and obstacles. The exhibition of illuminating large and malignant tumors, including tumor harboring lymph nodes could be distinguished easily from the surrounding tissues. These could heighten the surgeon's performance for better oncological resections while enabling the preservation of critical surrounding structures.

\section{Conclusions}

In conclusion, ICG-enhanced fluorescence-guided imaging is a potentially useful technique that improves the identification of adrenal gland to enhance surgeons' performance. We believe that this method may give specific advantages especially in cases which require fine dissection such as partial adrenalectomies. However, further large randomized studies are needed to be done for more precise analyses.

\section{Acknowledgments}

Funding: None.

\section{Footnote}

Provenance and Peer Review: This article was commissioned by the Guest Editor (Özer Makay) for the series "Robotic Adrenalectomy" published in Gland Surgery. The article was sent for external peer review organized by the Guest Editor and the editorial office.

Conflicts of Interest: All authors have completed the ICMJE uniform disclosure form (available at http://dx.doi. org/10.21037/gs-2019-ra-06). The series "Robotic Adrenalectomy" was commissioned by the editorial office without any funding or sponsorship. The authors have no other conflicts of interest to declare.

Ethical Statement: The authors are accountable for all aspects of the work in ensuring that questions related to the accuracy or integrity of any part of the work are appropriately investigated and resolved.

Open Access Statement: This is an Open Access article distributed in accordance with the Creative Commons Attribution-NonCommercial-NoDerivs 4.0 International License (CC BY-NC-ND 4.0), which permits the noncommercial replication and distribution of the article with the strict proviso that no changes or edits are made and the original work is properly cited (including links to both the formal publication through the relevant DOI and the license). See: https://creativecommons.org/licenses/by-nc-nd/4.0/.

\section{References}

1. Manny TB, Pompeo AS, Hemal AK. Robotic partial adrenalectomy using indocyanine green dye with nearinfrared imaging: the initial clinical experience. Urology 2013;82:738-42.

2. Colvin J, Zaidi N, Berber E. The utility of indocyanine green fluorescence imaging during robotic adrenalectomy. J Surg Oncol 2016;114:153-6. 
3. Arora E, Bhandarwar A, Wagh A, et al. Role of indocyanine green (ICG) fluorescence in laparoscopic adrenalectomy: a retrospective review of 55 Cases. Surg Endosc 2018;32:4649-57.

4. Kahramangil B, Berber E. The use of near infrared fluorescence imaging in endocrine surgical procedures. J Surg Oncol 2017;115:848-55.

5. Sound S, Okoh AK, Bucak E, et al. Intraoperative tumor localization and tissue distinction during robotic adrenalectomy using indocyanine green fluorescence imaging: a feasibility study. Surg Endosc 2016;30:657-62.

6. DeLong JC, Chakedis JM, Hosseini A, et al. Indocyanine green (ICG) fluorescence-guided laparoscopic adrenalectomy. J Surg Oncol 2015;112:650-3.

7. Fox IJ, Wood EH. Indocyanine green: physical and physiologic properties. Proc Staff Meet Mayo Clin 1960;35:732-44.

8. Alander JT, Kaartinen I, Laakso A, et al. A review of indocyanine green fluorescent imaging in surgery. Int J Biomed Imaging 2012;2012:940585.

9. Caldwell CB, Ricotta JJ. Changes in visceral blood flow with elevated intraabdominal pressure. J Surg Res 1987;43:14-20.

10. Kahramangil B, Kose E, Berber E. Characterization of fluorescence patterns exhibited by different adrenal tumours: determining the indications for indocyanine green use in adrenalectomy. Surgery 2018;164:972-7.

11. Boni L, David G, Mangano A, et al. Clinical applications of indocyanine green (ICG) enhanced fluorescence in laparoscopic surgery. Surg Endosc 2015;29:2046-55.

12. Speich R, Saesseli B, Hoffmann U, et al. Anaphylactoid reactions after indocyanine-green administration. Ann Intern Med 1988;109:345-6.

13. Hope-Ross M, Yannuzzi LA. Gragoudas ES, et al. Adverse reactions due to indocyanine green. Ophthalmology

Cite this article as: Agcaoglu O, Kulle CB, Berber E. Indocyanine green fluorescence imaging for robotic adrenalectomy. Gland Surg 2020;9(3):849-852. doi: 10.21037/gs2019-ra-06
1994;101:529-33.

14. Dip FD, Roy M, Perrins S, et al. Technical description and feasibility of laparoscopic adrenal contouring using fluorescence imaging. Surg Endosc 2015;29:569-74.

15. Moore EC, Berber E. Fluorescence techniques in adrenal surgery. Gland Surg 2019;8:S22-7.

16. Volkin D, Yerran N, Ahmed F, et al. Partial adrenalectomy minimizes the need for long-term hormone replacement in pediatric patients with pheochromocytoma and von HippelLindau syndrome. J Pediatr Surg 2012;47:2077-82.

17. Diner EK, Franks ME, Behari A, et al. Partial adrenalectomy: the National Cancer Institute experience. Urology 2005;66:19-23.

18. Benhammou JN, Boris RS, Pacak K, et al. Functional and oncologic outcomes of partial adrenalectomy for pheochromocytoma in patients with von Hippel-Lindau syndrome after at least 5 years of followup. J Urol 2010;184:1855-9.

19. Alesina PF, Hinrichs J, Meier B, et al. Minimally invasive cortical sparing surgery for bilateral pheochromocytomas. Langenbecks Arch Surg 2012;397:233-8.

20. Lerchenberger M, Gündogar U, Al Arabi N, et al. Indocyanine green fluorescence imaging during partial adrenalectomy. Surg Endosc 2020;34:2050-5.

21. Brunaud L, Bresler L, Ayav A, et al. Robotic-assisted adrenalectomy: What advantages compared to lateral transperitoneal laparoscopic adrenalectomy? Am J Surg 2008;195:433-8.

22. Walz MK, Petersenn S, Koch JA, et al. Endoscopic treatment of large primary adrenal tumours. Br J Surg 2005;92:719-23.

23. Castillo OA, Vitagliano G, Secin FP, et al. Laparoscopic adrenalectomy for adrenal masses: Does size matter? Urology 2008;71:1138-41. 